Jurnal The Messenger, Vol. 11, No. 1A, Special Issue on the School of Multimedia Technology and Communication Postgraduate Symposium, pp. 121-137

P-ISSN: 2086-1559, E-ISSN: 2527-2810

DOI: $10.26623 /$ themessenger.v11i1A.821

\title{
Strategic Factors for Building Brand Equity: Jordan Medical Tourism
}

\section{Faktor-faktor Strategis untuk Membangun Ekuitas Merek: Pariwisata Medis Yordania}

\author{
Fayez Bassam Shriedeh ${ }^{\mathbf{1}}$ \\ ${ }^{1}$ School of Hospitality and Tourism, Luminus Technical University College, \\ Airport Road, Amman 11118, Jordan \\ *Corresponding author, e-mail: f.shriedeh@1tuc.com
}

\begin{abstract}
Building a brand with strong equity is a vital element for differentiation and competitiveness, especially in today's highly competitive medical tourism. The literature indicated that Jordan has weak medical tourism brand equity. The contribution of customer relationship management and service quality in developing brand equity can't be ignored. Studies on marketing activities towards building brand equity remain limited. Accordingly, 650 selfadministrated questionnaires were distributed to outpatient medical tourists in Amman's five biggest hospitals using systematic sampling. After screening, 454 surveys were used for analysis using structural equation modelling. The results indicated that customer relationship management significantly impacted service quality and brand equity. Service quality strongly influenced brand equity, and brand equity was enhanced indirectly through service quality. This study highlighted the importance of such factors on brand equity-building activities in Jordanian medical tourism context. Further research is recommended to expand the proposed model.
\end{abstract}

Keywords: Service Quality, Brand Equity, Medical Tourism, Jordan.

\begin{abstract}
Abstrak
Membangun merek dengan ekuitas yang kuat merupakan elemen vital untuk diferensiasi dan daya saing, terutama di bidang pariwisata medis yang sangat kompetitif saat ini. Literatur menunjukkan bahwa Yordania memiliki ekuitas merek pariwisata medis yang lemah. Kontribusi manajemen hubungan pelanggan dan kualitas layanan dalam mengembangkan ekuitas merek tidak dapat diabaikan. Studi tentang kegiatan pemasaran untuk membangun ekuitas merek masih terbatas. Dengan demikian, 650 kuesioner yang dikelola sendiri dibagikan kepada wisatawan medis rawat jalan di lima rumah sakit terbesar di Amman dengan menggunakan pengambilan sampel sistematis. Setelah penyaringan, 454 survei digunakan untuk analisis menggunakan pemodelan persamaan struktural. Hasil menunjukkan bahwa manajemen hubungan pelanggan secara signifikan mempengaruhi kualitas layanan dan ekuitas merek. Kualitas layanan sangat mempengaruhi ekuitas merek, dan ekuitas merek ditingkatkan secara tidak langsung melalui kualitas layanan. Studi ini menyoroti pentingnya faktor-faktor tersebut pada kegiatan membangun ekuitas merek dalam konteks pariwisata medis Yordania. Penelitian lebih lanjut direkomendasikan untuk memperluas model yang diusulkan.
\end{abstract}

Kata Kunci: Kualitas Layanan, Ekuitas Merek, Pariwisata Medis, Yordania.

\section{Introduction}

Medical tourism is currently viewed as one of the most rapidly growing global economic generators in the world (Samadbeik et al., 2017). According to Ağaoğlu (2015), medical tourism promotes economic enhancement to a nation through employment opportunities and profit generation. For example, this industry is expected to generate an annual global gross profit of around USD 1 trillion in 2020, which is associated with $20 \%$ 
annual increases in medical tourists (Ağaoğlu, 2015). Besides that, in 2020, medical tourism is predicted to create around 300 million new work opportunities aligned with an approximately $9 \%$ increase in the total jobs (Noor, 2013).

In step with global development, medical tourism is fast becoming a keystone for Jordan's economic growth achievement (Dalbooh, 2015). In 2014, a total of 250,000 medical tourists were treated in Jordanian hospitals, which added more than USD 1 billion to the gross domestic product (Malkwai, 2015). Recognizing the great benefits resulting from medical tourism, Jordan's government is working diligently to become a leading medical tourism destination by 2020 .

However, with an increasing number of medical tourism destinations and emerging new markets, the competition has become aggressively intense (Han \& Hyun, 2015; Samadbeik et al., 2017). In such a competitive market place, building a strong medical tourism brand equity, which is considered as a central driver and a primary source of competitiveness and service differentiation, is deemed one ultimate goal for any medical destination (Chomvilailuk \& Srisomyong, 2016; Das \& Mukherjee, 2016). This is because of the power of identity, which creates a distinctive place in a potential customer's mind (Aaker, 1991; Keller, 1993). As a result, a brand that is superior to that of the competing brands will generate strong equity achievements in terms of promoting a strong brand image, enhancing brand loyalty, and establishing a preferable market share (Keller, 2013).

However, the growth rate of medical tourist arrivals to Jordan is unstable and has experienced fluctuations (Al Emam, 2016; Bani Mustafa, 2017). This fluctuation pattern supports the general argument that the medical tourism sector is increasingly competitive and further supports the notion that Jordanian medical tourism brands are suffering from low medical tourist-based brand equity. This situation calls for an urgent investigation of the potential marketing strategies that foster brand equity building from the perspective of medical tourists (Shriedeh \& Abd. Ghani, 2016; Shriedeh \& Ghani, 2017; Shriedeh \& Abd. Ghani, 2016; Shriedeh \& Ghani, 2017). In light of this need, Davcik, da Silva, and Hair (2015) have recommended 'continuous search for the determinants and sources of brand equity.'

From the perspective of tourist-based brand equity, Aaker (1991) emphasized the critical role of customers in identifying brand equity and conceptualized brand equity as a multidimensional construct that comprised brand equity asset dimensions including brand association, brand awareness, brand loyalty and perceived quality. Based on Aaker's (1991) view towards customers, Keller (1993) defined brand equity as 'the differential effect that brand knowledge has on consumer response to the marketing of that brand.' Thus, strong brand equity results from a customer's positive response to the marketing activity of the brand (Aprinta, Syamsiah, \& Hernofika, 2017) and, therefore, the management of the brand must invest in marketing actions that are directed to create a favourable response.

Regarding the above, (Yoo, Donthu, and Lee, 2000) incorporated the work of Aaker (1991) and Keller (1993)and proposed the idea of brand equity investigation concerning antecedents-brand equity assets in overall brand equity. In particular, Yoo et al. (2000) investigated the contribution of brand equity assets toward overall brand equity and examined the effect of marketing activities (e.g., price, store image, distribution intensity, advertising spending, and price promotion), which are represented as antecedents on brand equity assets. However, due to the limitations of their study, they recommended that other marketing actions beyond the 4P's of marketing mix activities should be

Jurnal The Messenger, Vol. 11, No. 1A, Special Issue on the School of Multimedia Technology and Communication Postgraduate Symposium, pp. 121-137 
investigated either directly or indirectly in different cultures, different settings, and different perspectives. Based on their recommendations, this current study partially adopted Yoo et al. (2000) framework and dealt with their limitations by proposing customer relationship management and service quality as direct predictors of brand equity building from the medical tourist perspective in the healthcare-medical tourism industry in Jordan.

Much attention and effort have been invested in examining brand-equity building activities. Previous studies have concentrated mainly on advertising (Asare \& Lei, 2017; Loureiro, Loureiro, Kaufmann, \& Kaufmann, n.d.; Yoo \& Donthu, 2002; Yoo et al., 2000), price (H. C. Chen \& Green, 2011; Dhurup, Mafini, \& Dumasi, 2014; Yoo \& Donthu, 2002), price promotion (Karunanithy \& Sivesan, 2013; Rajh, 2006; Yoo \& Donthu, 2002), country of manufacturing (Mostafa, 2015), country of origin (Loureiro \& Kaufmann, 2017; Mostafa, 2015), marketing communication activities (Bakshi, Bakshi, Mishra, \& Mishra, 2017; Šerić \& Šerić, 2017), trust (Y. S. Chen, 2010; Dib \& Alhaddad, 2014), and customer experience (A-Qader, K Omar, \& Rubel, 2017; Hepola, Karjaluoto, \& Hintikka, 2017; Zarantonello \& Schmitt, 2013). In addition, a tremendous amount of brand equity building research has been conducted on product categories and in Western countries (Mahfooz, 2015; Mukherjee \& Shivani, 2016). However, few empirical studies have examined the effect of customer relationship management (King \& King, 2017) and service quality (Ha, 2009; Keller \& Lehmann, 2006; Shriedeh \& Ghani, 2017) as antecedents of brand equity in healthcare-medical tourism brands (Vinh, Nga, \& Nguyen, 2017) or in the Jordanian context (Al-Azzam, 2013). Therefore, the contribution of this research makes an effort to connect the two separated constructs named customer relationship managemen and service quality into an integrated brand equity framework.

Customer relationship management, which aims to maintain long and lasting relationship with customers, has contributed significantly to customer-based brand equity building in different settings (Shriedeh \& Ghani, 2017). According to Battor \& Battor (2010), studying the management of the relationship with customers is a great opportunity for medical tourism management to understand the requirements of customers and to respond quickly to their requirements, which is critical for maximizing customer enhancements. However, despite the great interest shown by scholars in customer relationship management, no single agreed upon definition of customer relationship management exists in part because of the differing industry perspectives and other factors that have been employed in its study (Mohammed \& Rashid, 2012; Rashid \& Tahir, 2013). Zablah, Bellenger, and Johnston (2004) indicated that customer relationship management could be partitioned into five main categories related to: process, philosophy, capability, technology, and strategy. From a strategic perspective, which is one of the most widely accepted and used in the literature, Sin, Alan, and Yim (2005) defined customer relationship management as 'comprehensive strategy and process that enables an organization to identify, acquire, retain and nurture profitable customers by building and maintain long-term relationships with them.'

Accordingly, this study borrowed this definition and integrated different dimensions of customer relationship management into one construct. These dimensions are conditional factors for customer relationship management success including: customer participation/involvement, joint problem solving, long-term association, knowledge management, and technology-based CRM (Shriedeh \& Ghani, 2017). In addition, Akroush, Dahiyat, Gharaibeh, and Abu-Lail, 2011 indicated that viewing customer relationship management from the limited perspective of management is 
insufficient because the perspectives of customers must also be considered. Similarly, Demo, Watanabe, Chauvet, and Rozzett (2017) emphasized that 'the evaluation of CRM in the consumer market (B2C), filling a gap in the literature.' Accordingly, this current study addressed this gap in respond to these calls.

Several scholars have indicated that creating successful relationships with customers can also contribute to an organization's added value in a highly competitive business market and can lead to important outcome performance. For example, customer relationship management can reinforce customer retention (Ghahfarokhi \& Zakaria, 2009), customer value (Shofiah, 2017), and customer satisfaction (Khalafinezhad \& Long, 2013; Shofiah, 2017). In addition, Alipour and Mohammadi (2011) and Kasim and Minai (2009) indicated that maintaining a good relationship can lead to the creation of positive behaviours, which, in turn, can create a competitive advantage.

Empirical investigation also revealed that customer relationship management is a key source of brand equity building. For instance, Marinova, Cui, and Marinov (2008) investigated the direct path between customer relationship management and brand equity assets (perceived quality, brand loyalty, and brand associations/awareness) in addition to overall brand equity in the banking sector of China. The results indicated that customer relationship management significantly enhances brand equity assets and overall brand equity. Similarly, Marinova, Cui, Shiu, and Marinov (2012) empirically investigated customer relationship management with respect to customer perceptions of quality, loyalty and brand associations/awareness. The findings revealed that customer relationship management is a critical success factor for enforcing overall brand equity and its assets. Furthermore, Kim, Kim, Kim, Kim, and Kang (2008) indicated that maintaining strong relationship with patients has a significant and positive effect on Chinese hospitals brand equity. Based on the above discussion, the study proposed that:

H1: Customer relationship management has a significant effect on overall brand equity among medical tourists in Jordanian medical facilities.

Customer relationship management has also been considered as a valuable driver of service quality. Ang \& Buttle (2006) indicated that customer relationship practices are strongly associated with customer enhancements such as customer satisfaction, customer retention in addition to service quality. Nataraj (2010) emphasized that lengthy relationships with customers improve service quality, maintain market share, and reduce marketing activities costs. Empirical evidence has indicated that customer relationship management is a significant source of service quality. For example, Hafeez and Abbas (2017) investigated the effect of customer relationship management on service quality in the Pakistani banking sector. The results indicated that customer relationship management is a key predictor of service quality. Also, customer relationship has been found to provide a means to provide services of high quality (Saini \& Malik, 2014). According to the above discussion, this study hypothesized that:

$\mathrm{H} 2$ : Customer relationship management has a significant effect on service quality among medical tourists in Jordanian medical facilities.

Service quality is another critical strategy for enhancing the success of brands facing stiff competition. According to Aaker (1991), service quality is the core element of customer-based brand equity and a critical factor for achieving competitive advantage and brand differentiation. Parasuraman, Zeithaml, and Berry (1988)) defined service quality as 'a global judgment, or attitude, relating to the superiority of the service.' Parasuraman et al. (1988) also defined service quality as 'the discrepancy between consumers' perceptions of services offered by a particular firm and their expectations

Jurnal The Messenger, Vol. 11, No. 1A, Special Issue on the School of Multimedia Technology and Communication Postgraduate Symposium, pp. 121-137 
about firms offering such services.' This definition reflects the gap between the perceptions of customers of service brands and their expectations (Parasuraman, Zeithaml, \& Berry, 1985).

This gap is well known as the gap model, which has been operationalized by the Service Quality Scale (SERVQUAL). This scale is partitioned into five dimensions, namely, tangibility, empathy, assurance, responsibility, and service reliability. However, Cronin Jr and Taylor $(1992,1994)$ proposed a new service quality measure based solely on the perception assessments of customers called the SERVPERF. The SERVPERF scale is like the SERVQUAL scale using the same underlying dimensions but without considering the assessment of customer expectations. The SERVPERF scale is more valid and reliable than SERVQUAL (Teas, 1993). Therefore, several scholars have applied SERVPERF in a variety of service settings such as tourism, hospitality, healthcare, higher education, telecommunication, banking, and airlines, and the scale has and become one of the most applied service quality models (Shriedeh \& Ghani, 2017). Accordingly, this scale is applied in this study.

Undoubtedly, service quality in a service setting is different from that of a product setting due to the characteristics of service in terms of intangibility, inseparability, perishability, and variability, which make it difficult evaluate. This means that the service quality evaluation process differs according to service context, performance of the employees, time, location, and individual perceptions (Fuentes, 1999) and thus, different customers will evaluate the same service differently. Nevertheless, perceived quality is seen as being a precursor to behavioral manifestations of brand equity (Aaker, 1991). For instance, word of mouth (Molinari, Abratt, \& Dion, 2008), customer retention (Rust, Zahorik, \& Keiningham, 1995), brand trust (Osman \& Sentosa, 2013), willingness to pay a high price (Zeithaml, Berry, \& Parasuraman, 1996), intention to purchase (Aliman \& Mohamad, 2013), and customer satisfaction (Aliman \& Mohamad, 2013; Hapsari, Clemes, \& Dean, 2017; Rust et al., 1995). Moreover, the consequences of service quality on a firm's added value have also been empirically investigated. For example, Achmad (2015), Aspizain (2016), and Ming, Wei, Lee, Ong, and Su-Mae (2012) found service quality to be a driver of brand loyalty and brand image. In addition to brand loyalty and brand image, service quality can also influence significantly a firm's brand equity (Chahal \& Bala, 2012; Hirut, 2015; Mourad, Ennew, \& Kortam, 2011). Based on the stated discussion, this study proposed that:

H3: Service quality has a significant effect on overall brand equity among medical tourists in Jordanian medical facilities.

Azadi, Yousefi, and Eydi (2015), Murtiasih, Sucherly, and Siringoringo (2014), and Severi and Ling (2013), emphasized the role of customer perceptions towards service quality as a key mediating variable in their empirical investigation to the sourcesperceived quality-linkages. Along the same line, Yoo et al. (2000) argued that if a marketing activity (e.g., customer relationship management) influences brand equity or its assets significantly, then brand equity building could also be enhanced indirectly, and, thus, perceived quality serves as a mediator. Moreover, the successful maintenance of high quality service will help facilitate the implementation of customer relationship management practices (Mourad et al., 2011), specifically in a knowledge-based era, to develop superior customer value such as brand equity (Shriedeh \& Ghani, 2017). Although, this argument has been clarified, little empirical evidence has been employed to support it. Therefore, regarding this discussion, this study proposed that: 
H4: Service quality mediates the relationship between customer relationship management and overall brand equity among medical tourists in Jordanian medical facilities.

\section{Methodology}

Prior studies have focused on brand equity conceptualization, consequences, and interrelationship among brand equity assets (Šerić \& Šerić, 2017). Therefore, the aim of this study was to examine empirically the mediating role of service quality between customer relationship management and overall brand equity in Jordan, particularly in the medical tourism industry. Accordingly, this empirical research followed the quantitative research stream using a primary data source through implementing a self-administrated questionnaire (Aprinta et al., 2017; Sari, 2018). The target population in this particular study was the outpatient foreign tourists who were treated in the Jordanian private hospitals. The selection of outpatients was because most medical tourists in Jordan are outpatients. Six branded and biggest private hospitals located in Amman, which is a medical tourist hub, were invited to participate. However, only five hospitals agreed to be involved in this study, namely the Jordan, Islamic, Arab Medical Center, Specialty, and Al-Isra'a hospitals.

Aligning with recommendation of (Burns \& Bush, 2010), a confidence interval method was used for determining the sample size. According to their recommendation for the confidence interval approach, the suggested sample size was 384 . To avoid human bias and the non-response rate, a total of 650 questionnaires were distributed among outpatient medical tourists in the five branded and biggest hospitals in Amman using a systematic random sampling technique, whereby every 4th respondent was chosen and asked to participate in this study. The systematic random number of every $4^{\text {th }}$ respondent was chosen based on a random number table. Over a two-months period in October and November of 2017, data were collected with the help of two research assistants. Of the 650 distributed questionnaires, 589 questionnaires were returned representing a response rate of $90.6 \%$ through filter data screening and cleaning, 454 valid data sets were analysed using IBM-SPSS v. 21 and IBM-AMOS v. 21.

All the measurement scales used in the questionnaire were adapted from existing literature with minor wording modifications to fit the study context. For instance, 24 items were used to measure the five dimensions of customer relationship management, namely, customer involvement/participation ( 5 items), joint problem solving ( 3 items), long-term association (6 items), knowledge management (4 items), and technology-based CRM (6 items). All the above-mentioned items were taken from Lin, Chen, and Chiu (2010) and Sin et al. (2005). Meanwhile, 22 items were used to measure the five dimensions of the service quality construct. These were: tangibility of service (4 items); assurance (4 items) and further empathy (5 items) that, were taken from Aliman and Mohamad (2013) Reliability of service (4 items) that were taken from Ramseook-Munhurrun, LukeaBhiwajee, and Naidoo (2010), and responsiveness (5 items) that were taken from Chakravarty (2011) and Ramseook-Munhurrun et al. (2010). In addition, overall brand equity was measured using 10 items taken from Vatjanasaregagul (2007). According to Awang, Afthanorhan, and Mamat (2016) 'the researchers have to construct their questionnaire as interval scales if interested to apply the parametric test.' Therefore, all the measurement scales used a 7-point interval Likert-type with answers ranging from 'strongly disagree' (1) to 'strong agree' (7). Two different versions of the questionnaires were used, Arabic and English. The Arabic questionnaire was translated using a blind translation-back-translation method (Zikmund, Babin, Carr, \& Griffin, 2009).

Jurnal The Messenger, Vol. 11, No. 1A, Special Issue on the School of Multimedia Technology and Communication Postgraduate Symposium, pp. 121-137 
The initial questionnaire was validated technically via content validity and nontechnically via face validity. The content validity was assessed and validated through a panel of experts in the health and medical tourism industry in Jordan. Because of this phase, several dobule-barrelled questions were divided into two questions, and duplicate questions were deleted. In addition to content validity, the face validity was evaluated through a pilot study on 100 respondents, which was conducted in September 2017 and used for Exploratory Factor Analysis. As a result, one item was added to the customer involvement/participation scale, and two items were deleted from the long-term association scale. Besides, one item was deleted from the responsiveness of service quality scale, and one item was added to overall brand equity. Overall, the measurement scale for the proposed variables were: customer relationship management (23 items), service quality (21 items), and overall brand equity (11 items).

\section{Results and Discussion}

The descriptive analysis showed that most respondents were men $(60 \%)$ and married (66.7\%), the majority ranged in age between 36 and $45(30.8 \%)$ and most were bachelor's degree holders (47.5\%). Moreover, around 55\% of respondents earned less than USD 1000/monthly. In addition, the largest proportion were being treated under government support (38.9\%). Last, all the respondents were from the Middle East and North Africa. Of these, most originated from Yemen (30.1\%) and Libya (25.7\%).

EFA (using the principle component method with varimax rotation) was employed on a pilot study data set of 100 to validate the proposed constructs. In line with Awang's (2012) guidelines, four assumptions were followed: a minimum factor loading for each measurement item of 0.6; Kaiser-Meyer-Olkin (KMO) of sampling adequacy of above 0.6; a minimum eigenvalue for each component of 1; and a significance level of Bartlett's test of Sphericity (p) of 0.00 . The evaluation of EFA on customer relationship management, service quality, and overall brand equity showed that all the factors were extracted with an eigenvalue of above 1 , factor loadings were above 0.6 , the KMO of Sampling Adequacy was more than 0.6, and the significance level for Bartlett's test of Sphericity was 0.00. Appendix 1 shows the results of EFA and their respective values. For example, the five factors of customer relationship management explained $76.521 \%$ of the total variance with eigenvalues of more than 1 ranging from 1.229 to 6.373 supported with KMO values of 0.824 that were above the threshold of 0.6 and a $p$ value of 0.00 for Bartlett's test of Sphericity. In addition, all remaining items (18) had loadings of more than 0.6 ranging from 0.679 to 0.898 . However, five items were deleted due to poor loading (TBC4, CIP1, CIP3, CIP6, and LTA4).

In terms of service quality factorability, the results indicated that the five factors of service quality explained $83.790 \%$ of the total variance with eigenvalues of more than 1 , which ranged from 1.15 to 6.464 supported with $\mathrm{KMO}$ value of 0.815 which was above the thresholding of 0.6 and a $p$ value for Bartlett's test of Sphericity of 0.00 . In addition, 15 items had factor loadings of more than 0.6 ranging from 0.757 to 0.914 . Six items were eliminated due to weak factor loading (TAN2, REL1, RES,1, ASS3, EMP1, and EMP3).

Besides, overall brand equity explained $77.200 \%$ of the total variance with eigenvalue of $3.860>1$ and supported with KMO with a value of $0.819>0.6$. Of the 11 items used to measure overall brand equity, only 5 items (OBE1, OBE5, OBE7, OBE9, OBE10, and OBE11) remained with factor loadings of more than 0.6 ranging from 0.847 to 0.913 . 
Overall, the examination of EFA resulted in 38 valid items to measure customer relationship management (18), service quality (15) and overall brand equity (5). Furthermore, the values of Cronbach's alpha of internal consistency for each construct and their respective measure were above the threshold of 0.7 (Hair, Black, Babin, Anderson, \& Tatham, 2010). For instance, customer relationship management measures had a Cronbach's alpha of 0.915 for technology based-CRM, 0.891 for knowledge management, 0.893 for customer involvement/participation, 0.810 for long-term association, and 0.789 for joint problem solving. Meanwhile, the Cronbach's alpha values for each component of the service quality scale (tangibility (0.923), reliability (0.910), empathy (0.908), responsiveness (0.871) and assurance (0.811)), indicated a satisfactory reliability index. Besides, the overall brand equity showed a high value of Cronbach's alpha (0.928) exceeding the minimum requirements of 0.70 .

To further provide support for the implementation scale, Confirmatory Factor Analysis (CFA) was conducted to confirm the unidimensionality at the first step and then convergent validity, discriminant validity, construct validity, and reliability. According to (Awang, 2014, 2015), the validation process entails both the measurement model and the structural model. However, for complex models that include first order and second order constructs, the CFA can be made for each latent construct individually and then simplified and combined into a pooled-CFA measurement model. In line with (Hair, Black, Babin, Anderson, \& Tatham, 2010) suggestions, unidimensionality is confirmed when all items have minimum factor loadings of 0.5 . The convergent validity is also verified when the Average Variance Extracted (AVE) is 0.5 or more Awang, (2014, 2015). Discriminant validity is achieved when the square root of AVE for all constructs is higher than the correlation between the respective constructs. Awang (2015) further emphasized that construct validity 'is achieved when the Fitness Indexes for a construct achieved the required level.' In this sense, the widely cited fitness indexes are: GFI $>0.9$, RMSEA < 0. 08, CFI > 0.90, and ratio < 3 (Awang, 2015). In addition, reliability is confirmed when the Composite Reliability (CR) is 0.7 or more (Hair, J. F. et al., 2010).

Based on the above discussion, CFA was conducted on each construct separately; however, the results indicated that 2 items of the customer relationship management (KNM4 and CIP 3) and 4 items of the service quality (REL2, RSP1, ASS1, and EMP3) were loaded weakly on their respective latent constructs. Therefore, these items were deleted, resulting in a good model fit and confirming the validity and reliability for each construct.

Furthermore, the evaluation of the pooled-CFA measurement model produced a valid and reliable model. For example, all customer relationship management dimensions had loadings of more than 0.5 ranging from 0.66 to 0.85 , service quality dimensions had loadings ranging from 0.76 to 0.88 , in addition, the overall brand equity measures had loading ranging from 0.84 to 0.91 . In addition, the convergent validity was also confirmed producing an AVE value of more than 0.5, customer relationship management (0.57), service quality (0.677), and overall brand equity (0.775).

Last, all the criteria for fitness indexes were met further supporting the construct validity (ratio $=2.762<3, \mathrm{RMSEA}=0.067<0.08$, GFI $=0.929>0.9$, and $\mathrm{CFA}=0.965$ $>0.9$ ). Besides, the assessment of discriminant validity indicated that validity was achieved because the square root of AVE (the diagonal values in bold) was bigger than the correlation between any other constructs as seen in Table 1.

Jurnal The Messenger, Vol. 11, No. 1A, Special Issue on the School of Multimedia Technology and Communication Postgraduate Symposium, pp. 121-137 
Table 1. Discriminant Validity Index (source: Author's analysis)

\begin{tabular}{cccc}
\hline Construct & CRMC & SQC & OBE \\
\hline Customer Relationship Management (CRMC) & 0.757 & - & - \\
Service Quality (SQC) & 0.44 & 0.823 & - \\
Overall Brand Equity (OBE) & 0.59 & 0.46 & 0.88 \\
\hline
\end{tabular}

Moreover, the model shows a good level of reliability exceeding the threshold of 0.7 (Hair, et al., 2010). For instance, the CR for customer relationship management was 0.870 , service quality was 0.913 , and overall brand equity was 0.945 . All the above explanations are shown in Appendix 2. Awang (2015) emphasized conducting normality assessment for every measure before proceeding with structural equation modelling and further stressed that 'the absolute value of skewness of 1.0 or lower indicates the data is normally distributed.' Based on the outputs, the absolute value of skewness for all measures fell within the range of -1.103 and 0.403 indicating that the data was derived from a normal distribution.

To test the hypotheses, a further assessment for the structural model was made. The results indicated that the data fit the model very well in terms of fitness indexes and factor loading as seen in Figure 1.

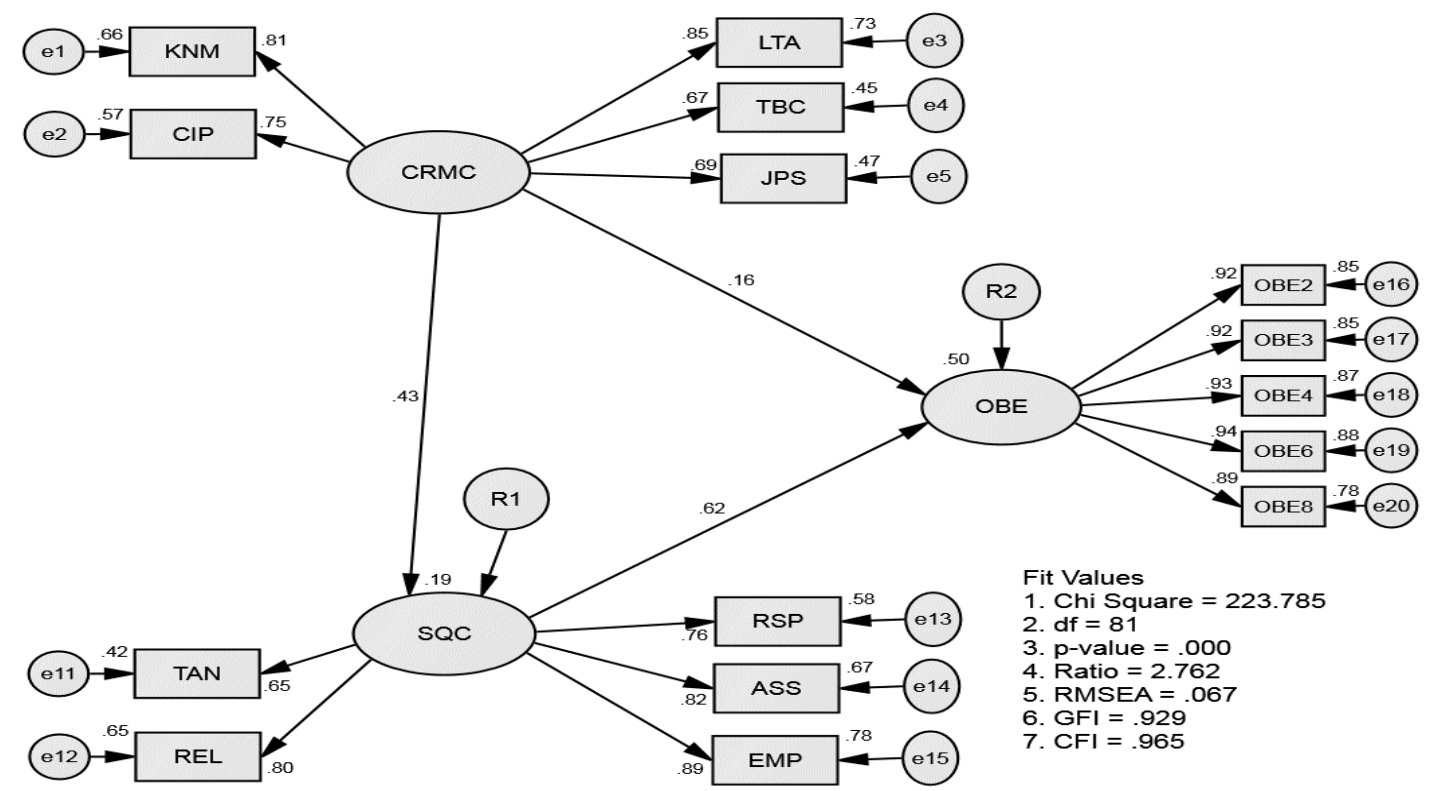

Figure 1. The Results of Structural Model Evaluation (source: Author's analysis) $\mathrm{KNW}=$ Knowledge Management, CIP = Customer Involvement, LTA = Long-term Association, TBC $=$ Technology-based CRM, JPS $=$ Joint Problem Solving, TAN $=$ Tangibility, REL $=$ Reliability, $\mathrm{REP}=$ Responsiveness, $\mathrm{ASS}=$ Assurance, $\mathrm{EMP}=$ Empathy.

The results of path analysis revealed that customer relationship management has a significant effect on both service quality $(\beta=0.422$, C.R value $=7.995, p>0.001)$ and overall brand equity $(\beta=0.253, C . R$ value $=3.936, p>0.001)$. In addition, service quality significantly affected overall brand equity $(\beta=0.524, C . R$ value $=10.076, p>0.001)$. Thus, H1, H2, and H3 were supported. Furthermore, the mediation test using the triangle method as Awang (2015) proposed indicated that service quality plays a partial mediator role between customer relationship management and overall brand equity because the indirect path $(0.43 \times 0.62=0.266)$ was larger than the direct path $(0.16)$. The direct path 
remains significant after service quality (the mediator) enters the model. Thus, $\mathrm{H} 4$ is also supported.

Furthermore, based on the Coefficient Determination value (R1 and R2) as shown in Figure 1, customer relationship management manage explains $19 \%$ of service quality variance while both customer relationship management and service quality explained $50 \%$ of overall brand equity. Service quality shows a stronger effect on overall brand equity $(\beta=0.524)$ than does customer relationship management $(\beta=0.253)$. Along the same line, the influence of customer relationship on service quality $(\beta=0.422)$ is larger than its effect on overall brand equity $(\beta=0.253)$. Despite the significant role of customer relationship management in brand equity building (direct path $=0.16$ ), its effect through service quality is stronger (indirect path $=0.266$ ). Thus, service quality is an essential factor in brand equity development.

This empirical research paper investigated the indirect effect of service quality on the relationship between customer relationship management and overall brand equity in the Jordanian medical tourism market. This research found that customer relationship management and service quality are significant predictors of overall brand equity and further enhanced the role of service quality as a key mediating variable. The results demonstrated that customer relationship management has a significant and positive impact on overall brand equity, and this result aligns with previous empirical investigation (Kim et al., 2008). Moreover, this result further supports the argument made by Aaker (1996) that strong brand equity is usually based upon maintaining a strong relationship with customers (Aaker \& Joachimsthaler, 2000). Thus, the finding is in general agreement with customer relationship management scholars that a good relationship with customer is a significant success strategy for subjective performance achievements such as brand equity (Marinova et al., 2012; Marinova et al., 2008). Therefore, medical tourism decision makers are encouraged to strengthen the relationship with medical tourists to develop brand equity.

Furthermore, the finding indicated that customer relationship management is a significant driver of service quality. The introduction of customer relationship management as a significant predictor of service quality further enhanced the argument made by Saini and Malik (2014) that customer relationship applications shorten the distance between a firm and their customers, which results in an enhancement of service quality. Furthermore, this result further confirmed the general notion that, to remain competitive in a highly stiff competitive market place, building closer ties with customers through customer relationship capabilities, especially in this information era, is an effective strategy to achieve service quality betterment (Keller, 2013). Such a result also seems consistent with the empirical investigations of Nataraj (2010), and Hafeez and Abbas (2017). Therefore, this study provides strong evidence that could help strategic decision makers in the medical tourism industry to invest in implementing strong customer relationship management activities for the sake of boosting the quality of service.

The result of this study also demonstrated that service quality is a critical source of overall brand equity. As mentioned previously, service quality has the strongest effect on overall brand equity. This result is consistent with the findings of existing studies on overall brand equity such as Aspizain (2016) and Yoo et al. (2000). The result presented herein supports the argument put forward by Aaker $(1991,1996)$ and Keller (2013) that providing a superiority in service quality produces significant results pertaining to service differentiation and thus promotes brand equity building (Shriedeh \& Abd. Ghani, 2018).

Jurnal The Messenger, Vol. 11, No. 1A, Special Issue on the School of Multimedia Technology and Communication Postgraduate Symposium, pp. 121-137 
In addition, the results present strong empirical evidence for the critical role of service quality as a key mediating construct between customer relationship management and overall brand equity. This result is in line with the results of prior investigations on the mediating role of service quality between marketing activities and overall brand equity (Azadi et al., 2015; Severi \& Ling, 2013).

\section{Conclusion}

Based on the above discussed results, the conclusion can be made that strong brand equity should create an advantage over competitors. Adding customer relationship management and service quality often provide a key to competitive distinctiveness. This study adds considerable empirical evidence to the customer-based brand equity theory. Overall, customer-based brand equity theory predicts that marketing activities can foster positive customer attitudes and responses toward a brand, either directly or indirectly (Shriedeh \& Abd. Ghani, 2018; Yoo et al., 2000). The theoretical implication of this research is consistent with Yoo et al. (2000) investigation, but is different with the introduction of customer relationship management as another marketing strategy that can enhance brand equity building, particularly in the context of adding the Middle Eastern perspective using the service industry (medical tourism) context. In addition, the study also provides a comprehensive picture of customer relationship management measures based on the medical tourist point of view. This research also contributes to the existing knowledge by providing critical insights into the role of service quality as a direct and an indirect source of brand equity building using the SERVPERF model. Thus, decision makers and strategic management for medical tourism/healthcare medical services must tailor their strategic factors to build strong medical tourism brands with more of an emphasize on delivering higher levels of service quality.

However, despite the aforementioned contributions of this research, this study is limited to two predictors of brand equity, which were customer relationship management and service quality and service quality as a mediator in the context of the medical tourism service industry using the perspectives of outpatients. Therefore, future studies may replicate this model in different service contexts and in different developed and developing countries to add different perspectives. In addition, this study could be enhanced by investigating a one-to-one relationship between the underlying dimensions and by expanding the current model.

\section{Acknowledgements}

I would like to thank School of Multimedia Technology and Communication (SMMTC), Universiti Utara Malaysia, especially Dr. Bahtiar Bin Mohamad who has given us this opportunity to participate in research activities.

\section{References}

A-Qader, I., Omar, A. B. K., \& Rubel, M. R. B. (2017). The influence of affective brand experience dimension on brand equity of the smart phone millennial users in Malaysia. Management, 5(1), 25-37.

Aaker, D. A. (1991). Managing brand equity. New York, NY: The Free Press.

Aaker, D. A. (1996). Building strong brands. New York, NY: The Free Press. Retrieved from https://doi.org/10.2307/41165845

Aaker, D. A., \& Joachimsthaler, E. (2000). Brand leadership. New York, NY: The Free Press. 
Achmad, F. (2015). The effect of tourism service quality, tourist destination image and experience of tourist towards tourists' satisfaction, tourism word of mount, tourist destination preferences, and tourist destination loyalty (a study on foreign tourists in tourist dest. European Journal of Business and Management, 7(2), 95-103.

Ağaoğlu, S. (2015). Medical tourism assessment: Case of Izmir. Journal of Hospitality and Management Tourism, 8(4), 1-6.

Akroush, M. N., Dahiyat, S. E., Gharaibeh, H. S., \& Abu-Lail, B. N. (2011). Customer relationship management implementation: An investigation of a scale's generalizability and its relationship with business performance in a developing country context. International Journal of Commerce and Management, 21(2), 158190. Retrieved from https://doi.org/10.1108/10569211111144355

Al-Azzam, F. (2013). Analysis of the antecedents of customer-based brand equity and its application to multiple destinations. Interdisciplinary Journal of Contemporary Research in Business, 5(5), 71-90.

Al Emam, D. (2016). Number of medical tourists drops 30\% in Q1 of 2016. Retrieved April 9, 2018, from http://www.jordantimes.com/news/local/number-medicaltoursits-drops-30-q1-2016

Aliman, N. K., \& Mohamad, W. N. (2013). Perceptions of service quality and behavioral intentions: A mediation effect of patient satisfaction in the private health care in Malaysia. International Journal of Marketing Studies, 5(4), 15-29. Retrieved from https://doi.org/10.5539/ijms.v5n4p15

Alipour, M., \& Mohammadi, M. H. (2011). The effect of customer relationship management $(\mathrm{CRM})$ on achieving competitive advantage of manufacturing tractor. Global Journal of Business and Management Research, 11(5), 26-36.

Ang, L., \& Buttle, F. (2006). Customer retention management processes: A quantitative study. European Journal of Marketing, 40(1/2), 83-99.

Aprinta, G. E. B., Syamsiah, S., \& Hernofika, L. (2017). Social marketing strategy to make students awareness of throwing away garbage on the bin. Jurnal The Messenger, 9(3). Retrieved from https://doi.org/10.26623/themessenger.v9i2.516

Asare, I. T., \& Lei, S. (2017). Investigating the effect of selected marketing efforts in brand equity creation and its cross-cultural invariance in emerging markets. International Journal of Marketing Studies, 9(1), 91-108.

Aspizain, C. (2016). The effects of service quality and corporate rebranding on brand image, customer satisfaction, brand equity and customer loyalty: Study in advertising company at tvOne. Russian Journal of Agricultural and SocioEconomic Sciences, 60(12), 118-126.

Awang, Z. (2014). A handbook on SEM for academicians and practitioners: The step by step practical guides for the beginners. Bandar Baru Bangi: MPWS Rich Resources.

Awang, Z. (2015). SEM made simple: A gentle approach to learning structural equation modeling. Selangor, Malaysia: MPWS Rich Publication.

Awang, Z., Afthanorhan, A., \& Mamat, M. (2016). The Likert scale analysis using parametric based Structural Equation Modeling (SEM). Computational Methods in Social Sciences, 4(1), 13-21.

Azadi, R., Yousefi, B., \& Eydi, H. (2015). The impact of brand country-of-origin image on the formation of brand equity in the sports apparel industry. Universal Journal of Industrial and Business Management, 3(3), 67-73.

Bakshi, M., Bakshi, M., Mishra, P., \& Mishra, P. (2017). Drivers of brand equity of

Jurnal The Messenger, Vol. 11, No. 1A, Special Issue on the School of Multimedia Technology and Communication Postgraduate Symposium, pp. 121-137 
television news channels: Evidences from emerging market. Marketing Intelligence and Planning, 35(1), 147-162.

Bani Mustafa, A. (2017). Sector leader blames gov't for $40 \%$ decline in medical tourism. Retrieved April 9, 2018, from http://www.jordantimes.com/news/local/sectorleader-blames-gov't-40-decline-medical-tourism

Battor, M., \& Battor, M. (2010). The impact of customer relationship management capability on innovation and performance advantages: Testing a mediated model. Journal of Marketing Management, 26(9-10), 842-857. Retrieved from https://doi.org/10.1080/02672570903498843

Bhabha, H. K. (2012). The Location of Culture. Routledge. https://doi.org/10.1080/09700161003659111

Burns, A. C., \& Bush, R. F. (2010). Marketing research. Upper Saddle River, N.J: Prentice Hall.

Chahal, H., \& Bala, M. (2012). Significant components of service brand equity in healthcare sector. International Journal of Health Care Quality Assurance, 25(4), 343-362.

Chakravarty, A. (2011). Evaluation of service quality of hospital outpatient department services. Medical Journal Armed Forces India, 67(3), 221-224.

Chen, H. C., \& Green, R. D. (2011). Brand equity, marketing strategy, and consumer income: A hypermarket study. Journal of Management and Marketing Research, $8(1), 1-18$.

Chen, Y. S. (2010). The drivers of green brand equity: Green brand image, green satisfaction, and green trust. Journal of Business Ethics, 93(2), 307-319.

Chomvilailuk, R., \& Srisomyong, N. (2016). Three dimensional perceptions of medical/health travelers and destination brand choices: Cases of Thailand. Procedia-Social and Behavioral Sciences, 175, 376-383.

Cronin, Jr, J. J., \& Taylor, S. A. (1994). SERVPERF versus SERVQUAL : Reconciling performance-based and perceptions-minus-expectations measurement of service quality. Journal of Marketing, 58(1), 125-131. Retrieved from https://doi.org/10.2307/1252256

Cronin Jr, J. J., \& Taylor, S. A. (1992). Measuring service quality: A reexamination and extension. The Journal of Marketing, 56(3), 55-68. Retrieved from https://doi.org/10.2307/1252256

Dalbooh, M. A. A. (2015). Marketing Jordan as a regional medical service center (view point of employee). International Journal of Marketing Studies, 7(3), 107-119.

Das, G., \& Mukherjee, S. (2016). A measure of medical tourism destination brand equity. International Journal of Pharmaceutical and Healthcare Marketing, 10(1), 104128.

Davcik, N. S., da Silva, R. V, \& Hair, J. F. (2015). Towards a unified theory of brand equity: Conceptualizations, taxonomy and avenues for future research. Journal of Product and Brand Management, 24(1), 3-17.

Demo, G., Watanabe, E. A. D. M., Chauvet, D. C. V, \& Rozzett, K. (2017). Customer relationship management scale for the b2c market: A cross-cultural comparison. RAM. Revista de Administração Mackenzie, 18(3), 42-69.

Dhurup, M., Mafini, C., \& Dumasi, T. (2014). The impact of packaging, price and brand awareness on brand loyalty: Evidence from the paint retailing industry. Acta Commercii, 14(1), 1-9.

Dib, H., \& Alhaddad, A. (2014). The hierarchical relationship between brand equity 
dimensions. European Scientific Journal, 10(28), 183-194.

Fuentes, C. M. (1999). Measuring hospital service quality: A methodological study. Managing service quality. An International Journal, 9(4), 230-240.

Ghahfarokhi, A. D., \& Zakaria, M. S. (2009). The impact of CRM on customer retention in Malaysia. In International Conference on Electrical Engineering and Informatics (ICEEI'09 (pp. 309-313). IEEE.

Ha, H. Y. (2009). Effects of two types of service quality on brand equity in China: The moderating roles of satisfaction, brand associations, and brand loyalty. Seoul Journal of Business, 15(2), 59-83.

Hafeez, S., \& Abbas, T. (2017). Impact of CRM practices on service quality in the banking industry. Pakistani Administrative Review, 1(2), 130-144.

Hair, J. F., Black, W. C. J., Babin, B. J., Anderson, R. E., \& Tatham, R. L. (2010). Multivariate data analyisis (7th ed.). Upper Saddle River, NJ: Pearson Prentice Hall.

Han, H., \& Hyun, S. S. (2015). Customer retention in the medical tourism industry: Impact of quality, satisfaction, trust, and price reasonableness. Tourism Management, 46, 20-29.

Hapsari, R., Clemes, M. D., \& Dean, D. (2017). The impact of service quality, customer engagement and selected marketing constructs on airline passenger loyalty. International Journal of Quality and Service Sciences, 9(1), 21-40.

Hepola, J., Karjaluoto, H., \& Hintikka, A. (2017). The effect of sensory brand experience and involvement on brand equity directly and indirectly through consumer brand engagement. Journal of Product and Brand Management, 26(3), 282-293.

Hirut, S. (2015). The effect of service quality on customer based brand equity (a case of commercial bank of Ethiopia). Dissertation. Ethiopia.

Karunanithy, M., \& Sivesan, S. (2013). An empirical study on the promotional mix and brand equity: Mobile service providers. Industrial Engineering Letters, 3(3), 1-9.

Kasim, A., \& Minai, B. (2009). Linking CRM strategy, customer performance measures and performance in the hotel industry. International Journal of Economics and Management, 3(2), 297-316.

Keller, K. L. (1993). Conceptualizing, measuring, and managing customer-based brand equity. The Journal of Marketing, 557(1), 1-22. Retrieved from https://doi.org/10.2307/1252054

Keller, K. L. (2013). Strategic brand management: Building, measuring, and managing brand equity. (4th, Ed.). Upper Saddle River, NJ: Pearson Prentice Hall.

Keller, K. L., \& Lehmann, D. R. (2006). Brands and branding: Research findings and future priorities. Marketing Science, 25(6), 740-759.

Khalafinezhad, R., \& Long, C. S. (2013). Customer satisfaction and loyalty: A review in the perspective of CRM. Sains Humanika, 64(2), 61-66.

Kim, K. H., Kim, K. S., Kim, D. Y., Kim, J. H., \& Kang, S. H. (2008). Brand equity in hospital marketing. Journal of Business Research, 61(1), 75-82. Retrieved from https://doi.org/10.1016/j.jbusres.2006.05.010

King, C., \& King, C. (2017). Brand management-standing out from the crowd: A review and research agenda for hospitality management. International Journal of Contemporary Hospitality Management, 29(1), 115-140.

Lin, R. J., Chen, R. H., \& Chiu, K. K. S. (2010). Customer relationship management and innovation capability: An empirical study. Industrial Management and Data Systems, 110(1), 111-133. Retrieved from

Jurnal The Messenger, Vol. 11, No. 1A, Special Issue on the School of Multimedia Technology and Communication Postgraduate Symposium, pp. 121-137 
https://doi.org/10.1108/02635571011008434

Loureiro, S. M. C., \& Kaufmann, H. R. (2017). Advertising and country-of-origin images as sources of brand equity and the moderating role of brand typicality. Baltic Journal of Management, 12(2), 153-170.

Loureiro, S. M. C., Loureiro, S. M. C., Kaufmann, H. R., \& Kaufmann, H. R. (n.d.). No Title.

Mahfooz, Y. (2015). Brand equity-consequence relationship: Evidence from automobile industry. International Journal of Business and Management, 10(3), 81-90.

Malkwai, K. (2015). Medical tourism generates over JD1 billion in 2014. Retrieved March 25, 2018, from http://www.jordantimes.com/news/local/medical-tourismgenerates-over-jd1-billion-2014-

Marinova, S., Cui, J., Shiu, E., \& Marinov, M. (2012). Impact of customer relationships on brand equity in Chinese retail banking. Journal of Euromarketing, 21(1), 37-52.

Marinova, S. T., Cui, J., \& Marinov, M. A. (2008). Customer relationships and brand equity in China's banking services. Revista de Administracao Faces Journal, 7(3), $11-27$.

Ming, T. T., Wei, L. T., Lee, W. S. S., Ong, M. B. F., \& Su-Mae, T. (2012). Consumerbased brand equity in the service shop. International Journal of Marketing Studies, 4(4), 60-77.

Mohammed, A. A., \& Rashid, B. (2012). Customer relationship management (CRM) in hotel industry: A framework proposal on the relationship among CRM dimensions, marketing capabilities, and hotel performance. International Review of Management and Marketing, 2(4), 220-230.

Molinari, L. K., Abratt, R., \& Dion, P. (2008). Satisfaction, quality and value and effects on repurchase and positive word-of-mouth behavioral intentions in a B2B services context. Journal of Services Marketing, 22(5), 363-373. Retrieved from https://doi.org/10.1108/08876040810889139

Mostafa, R. H. (2015). The impact of country of origin and country of manufacture of a brand on overall brand equity. International Journal of Marketing Studies, 7(2), 70-83. Retrieved from https://doi.org/10.5539/ijms.v7n2p70

Mourad, M., Ennew, C., \& Kortam, W. (2011). Brand equity in higher education. Marketing Intelligence and Planning, 29(4), 403-420.

Mukherjee, S., \& Shivani, S. (2016). Marketing mix influence on service brand equity and its dimensions. Vision: The Journal of Business Perspective, 20(1), 9-23.

Murtiasih, S., Sucherly, S., \& Siringoringo, H. (2014). Impact of country of origin and word of mouth on brand equity, 32(5), 616-629.

Nataraj, S. (2010). Customer retention-CRM application. Issues in Informations Systems, 11(2), 44-47.

Noor, R. (2013). Outbound medical tourism from Bangladesh: Problems and solutions. University of Greenwich.

Osman, Z., \& Sentosa, I. (2013). Influence of customer satisfaction on service quality and trust relationship in Malaysian rural tourism. Business Management Quarterly Review, 4(2), 12-25.

Parasuraman, A., Zeithaml, V. A., \& Berry, L. L. (1985). A conceptual model of service quality and its implications for future research. The Journal of Marketing, 49(9), 41-50.

Parasuraman, A., Zeithaml, V. A., \& Berry, L. L. (1988). Servqual: A multiple-item scale for measuring consumer perspectives of service quality. Journal of Retailing, 64(1), 
$12-22$.

Rajh, E. (2006). The effects of marketing mix elements on brand equity. Croatian Economic Survey, 14(8), 53-80.

Ramseook-Munhurrun, P., Lukea-Bhiwajee, S. D., \& Naidoo, P. (2010). Service quality in the public service. International Journal of Management and Marketing Research, 3(1), 37-50.

Rashid, B. B., \& Tahir, S. B. (2013). Assessing the influence of customer relationship management (CRM) dimensions on organization performance: An empirical study in the hotel industry. Journal of Hospitality and Tourism Technology, 4(3), 228247. Retrieved from https://doi.org/10.1108/JHTT-01-2013-0002.

Rust, R. T., Zahorik, A. J., \& Keiningham, T. L. (1995). Return on quality (ROQ): Making service quality financially accountable. The Journal of Marketing, 59(2), 58-70.

Saini, S., \& Malik, H. (2014). The impact of customer relationship management on the service quality of the star rated hotels in Jalandhar and Ludhiana. International Journal of Informative and Futuristic Research, 10(1), 174-185. Retrieved from https://doi.org/10.1007/s11002-009-9096-z.

Samadbeik, M., Asadi, H., Mohseni, M., Takbiri, A., Moosavi, A., \& Garavand, A. (2017). Designing a medical tourism website: A qualitative study. Iranian Journal of Public Health, 46(2), 249-257.

Sari, A. A. (2018). The akat Politeknik Indonusa Surakarta. Jurnal The Messenger, 10(1), 93. Retrieved from https://doi.org/10.26623/themessenger.v10i1.417

Šerić, M., \& Šerić, M. (2017). Relationships between social Web, IMC and overall brand equity: An empirical examination from the cross-cultural perspective. European Journal of Marketing, 51(3), 646-667.

Severi, E., \& Ling, K. C. (2013). The mediating effects of brand association, brand loyalty, brand image and perceived quality on brand equity. Asian Social Science, 9(3), 125-137.

Shofiah, S. (2017). Study of influence of customer relationship management on customer satisfaction in CV Batik Semarang. Journal of Marketing Science, 16(1), 57-69.

Shriedeh, F. B., \& Abd. Ghani, N. H. (2016). Service quality as an antecedent of brand equity: Empirical evidence in the medical tourism from Jordan. International Review of Management and Marketing, 7(1), 15-19.

Shriedeh, F. B., \& Abd. Ghani, N. H. (2018). The role of customer relationship management, service quality and innovation as sources of brand equity development. In Proceedings of the SMMTC Postgraduate Symposium: Advancing Research in Communication, Media and Multimedia: Theory Methodology and Applications (pp. 50-55). Malaysia: Universiti Utara Malaysia.

Shriedeh, F. B., \& Ghani, N. H. A. (2017). Impact of innovation on the relationship between customer relationship management and brand equity in the medical tourism of Jordan. Journal of Research in Business, Economics and Management, 7(4), 1150-1158.

Sin, L. Y., Alan, C. B., \& Yim, F. H. (2005). CRM: Conceptualization and scale development. European Journal of Marketing, 39(11/12), 1264-1290. Retrieved from https://doi.org/10.1108/03090560510623253

Teas, R. K. (1993). Expectations, performance evaluation, and consumers' perceptions of quality. The Journal of Marketing, 57(4), 18-34.

Vatjanasaregagul, L. (2007). The relationship of service quality, consumer decision

Jurnal The Messenger, Vol. 11, No. 1A, Special Issue on the School of Multimedia Technology and Communication Postgraduate Symposium, pp. 121-137 
factors and brand equity. Nova Southeastern University.

Vinh, T. T., Nga, V. T. Q., \& Nguyen, N. P. (2017). The causal relationships between components of customer-based brand equity for a destination: Evidence from South Korean tourists in Danang city, Vietnam. In Asian Economic and Financial Review (pp. 358-367). Danang city.

Yoo, B., \& Donthu, N. (2002). Testing cross-cultural invariance of the brand equity creation process. Journal of Product and Brand Management, 11(6), 380-398. Retrieved from https://doi.org/10.1016/S0148-2963(99)00098-3

Yoo, B., Donthu, N., \& Lee, S. (2000). An examination of selected marketing mix elements and brand equity. Journal of the Academy of Marketing Science, 28(2), 195-211. Retrieved from https://doi.org/10.1177/0092070300282002

Zablah, A. R., Bellenger, D. N., \& Johnston, W. J. (2004). An evaluation of divergent perspectives on customer relationship management: Towards a common understanding of an emerging phenomenon. Industrial Marketing Management, 33(6), 475-489. Retrieved from https://doi.org/10.1016/j.indmarman.2004.01.006

Zarantonello, L., \& Schmitt, B. H. (2013). The impact of event marketing on brand equity: The mediating roles of brand experience and brand attitude. International Journal of Advertising, 32(2), 255-280.

Zeithaml, V. A., Berry, L. L., \& Parasuraman, A. (1996). The behavioral consequences of service quality. The Journal of Marketing, 60(2), 31-46.

Zikmund, W., Babin, B., Carr, J., \& Griffin, M. (2009). Business Research methods (8th ed.). Boston, MA: South-Western, Cengage Learning. 